Published in Liam Campling and Jens Lerche (eds.), 'Special Issue: The Political Economy of Agrarian Change: Essays in Appreciation of Henry Bernstein' Journal of Agrarian Change, 16(3): 370-389

\title{
An Interview with Henry Bernstein ${ }^{1}$
}

Henry Bernstein was co-editor (with Terence J. Byres) of Journal of Agrarian Change between 2001 and 2008 and co-edited Journal of Peasant Studies (where he joined Byres) between 1985 and 2000. This interview highlights some of Bernstein's major pedagogical and theoretical contributions to the fields of agrarian political economy and development studies. To do so it traces his intellectual and political trajectory, providing important context for understanding his published work.

Keywords: Henry Bernstein, Marxism, agrarian political economy, development studies, Tanzania, South Africa

Could you tell us about your family background, where your parents were from and what they did for a living?

I was born in 1945 in London into a working class Jewish communist family. Our whole social universe in my first ten years was bounded by the Party which was so vigorous in our neighbourhood.

Both of my parents were second generation immigrants. Their parents had been part of the large wave of Jewish emigration from Eastern Europe and Russia after the 1905 Revolution and the pogroms. My grandfathers died around the time I was born, but my father's mother who I knew best - had been a tobacco factory worker in Odessa and was on the Left, almost instinctively you could say. She and her husband, like so many others, were on the move after the pogroms. They first went to Budapest and then to London. My father was the third of nine siblings and the first one to be born here, in 1916, in the Jewish ghetto in the East End of London that is now a strongly Bangladeshi area. When he was growing up in the 1930s he was in the Independent Labour Party before he joined the Communist Party (CP).

\footnotetext{
${ }^{1}$ This interview was conducted on 19 January 2015 at Queen Mary University of London by Gavin Capps and Liam Campling, and edited by them. We would like to thank Helena Pérez-Niño for the transcription.
} 
Because he and his best friend - who was my mother's brother, that's how he met my mother - were active Party members, once they got jobs, within a day or two they would be organizing and then thrown out on their ear. I remember my father speaking on a soap box on street corners - he was a very good public speaker - and I went on marches with him from an early age, including anti-colonial marches which may have stimulated my interest in what was happening in Asia and Africa.

My mum was a seamstress, which was so common among woman of that generation and social background. During the Second World War she worked in aircraft factories, the nimble fingers thing. They recruited seamstresses to do the wiring in military aircraft. She was also a Party member and was involved in the Party mobilization to open up London underground stations as bomb shelters, while my father spent six years in the Army.

\section{How did the activist atmosphere around home shape your early political formation?}

Our house in Stoke Newington was packed all the time with Party comrades many of whom were close neighbours. Nobody had any money and the big excitement was going to Epping Forest on Sundays in the summer. The local Party branch would fill several double decker buses and off we went with balls for games, picnics, and guitars. It was a very rich childhood.

My father was a charismatic figure and a great example of those autodidactic working class Party members of the time. He left school at 14, but he read a lot, had a razor-sharp mind and was a formidable debater. My mother's brother was a real hard-line Party member who worked all his life in Party organizations, for the Daily Worker and then for the Party publisher Lawrence and Wishart. When I was experimenting with other kinds of political ideas in my teens, we had lots of arguments and he would stamp on my youthful disagreement and ideas that were critical of the Party, but that did not take me outside Marxism, of course. I didn't really have any encounters with communists or leftists of any stripe from middle class or upperclass backgrounds until we left London and especially when I went to university.

When I was 10, we were resettled in one of the new London County Council estates because we were living in sub-standard housing. This was a move to an entirely different social milieu, near the 'stockbroker belt' of Reigate, Surrey. Of course, my parents joined the local Communist Party, but it was sociologically very different: mainly middle class and the branch much smaller than what we had known in Stoke Newington, which at that time could still mobilise three-quarters of the neighbourhood around certain issues. In the Reigate area, the Party wasn't even able to put up candidates for local elections. My mother suffered the most from the culture shock of our move, leaving behind the close comradeship and social vibrancy 
of her life in London, while my father continued to commute to work in London. They stayed politically active. They were strongly supportive of CND and deeply concerned with the Civil Rights struggle in the U.S. South. They found their contemporary political heroes there and in anti-colonial struggles, especially the anti-apartheid struggle: Mandela was my mum's number one world hero.

After the move, I started at a grammar school in Reigate. That was a very strange experience for me, but quite important formatively. There was only a small handful of kids from the housing estate where we lived, but I was equipped with an ideology from home that enabled me to survive a school that tried to pretend it was a minor public school. Nearly all of my teachers had been officers during the war and we were encouraged, or compelled in many cases, to address them by their army titles. But much of this was being challenged by the early 1960s; it was falling apart. I was one of the first kids at school to refuse to join the Officer Training Corps and then in the 1960s pupils started leaving it, an important step forward. I had good backing and support from my parents, but still it was a new and strange world to them when I talked about school, its class culture, and so on. As it happens, my best mates in school were from working class families. There was no formal political education in the Reigate Party branch - it was too small - but I read some socialist and Marxists texts and was very active in the anti-apartheid movement and CND (there was a certain amount of personal liberation in that!) and raised these issues at school too.

\section{Where did you go to university and what did you study?}

I first went to King's, which at that time (1964) was the most progressive college at Cambridge. It had a historical association with Eton, and the people I came into contact with through my interviews were very keen to recruit grammar school boys. Subsequently King's became among the first former men's colleges in Cambridge to admit women. Recently it had links with the Bloomsbury group and all that. Keynes had been the bursar, and when I was an undergraduate E.M. Forster was still living there. The students I became friendly with were mainly working class guys in my year and we were all very class conscious. I also got on with a few bohemian public school boys who I guess had their own fascination for me. I had never met anyone like them: very alternative, dope-smoking and so on. Then I had several good American friends. The people I hung around with were so intellectually curious, with that energy and appetite for ideas. We read and discussed a great deal. I was in the Communist Party but not a very committed or fervent member. Of course it was a very important moment for the Party after the Khrushchev revelations and I suppose I was experimenting with other 
kinds of political ideas. I was becoming more aware of Trotskyism then. But my main memory is of a camaraderie of the Left without sectarianism.

I originally went to read English Literature, then switched to History. Cambridge, and I presume Oxford as well, was so different than other British universities then, let alone now. Teachers really took an individual interest. If you had a problem you could go and talk to someone, they would advise you. It was all about opening up space for your individual development and of course there's a clear class history to all that. But it was a great privilege. There were people around who were world class scholars. There was no Sociology then at Cambridge, but there were younger people teaching History who knew social theory as well. While I didn't find most courses very stimulating - there was no world history to speak of there were some courses on political and social thought that really interested me. I was also interested in nineteenth century British history, which obviously was to do with the industrial revolution, the formation of an industrial working class, the context in which Marx wrote. But I was most drawn to the history of ideas because it had a more analytical edge and challenge, which was why I went on to do a Sociology Master's at the London School of Economics (LSE).

When you went to the LSE it was on the cusp of 1968, what can you tell us about that experience?

I had to do a two-year Master's for people coming in to Sociology from other subjects, so was at the LSE from 1967-1969. It was important for me, not so much for who was teaching then, but because of the people I met, comrades who were studying there and for the political moment as well. A key person for me was a Turkish visiting professor called Mübeccel Kıray. She had been one of the first women in Turkey to get a $\mathrm{PhD}$ (two in fact), had spent two years in prison, and was quite iconic for a group of us Sociology Master's students on the Left. It was through her that I subsequently went to teach in Turkey. I was with my fellow Masters students, reading informally in small groups and having lengthy debates. We would read the new Marxism of the time, the sort of thing that was being promoted by New Left Review and we also read a lot of new radical theory that was not necessarily Marxist, R.D. Laing and other radical psychoanalytical work, all sorts of stuff.

I had met my partner Renee at Cambridge and we already had one son before LSE. The second was born while I was there. We couldn't afford to live in London but stayed on the same housing estate as my mum and dad. Renee taught in a local secondary school and I commuted to London two or three days a week. When she was working, I did a lot of the child 
care. But while life at the LSE was different from where we lived, the social gap was nothing like at Cambridge. As it happens, again most of my mates were working class plus there were students from Latin America, Greece, Italy and the US. It was brilliant, very cosmopolitan and exciting. I also used to go to the School of Oriental and African Studies (SOAS) for lectures and courses on Africa. A lot of Africa had recently won independence and I wanted to make sense of it, including the beginnings of a critical Left analysis of the governments that had emerged from anti-colonial struggles.

I was involved in the movement against the US war in Vietnam, and no doubt imbibed some of the Third Worldism of that moment. This is when I started getting interested in Maoism. And there was France in 1968 and 1968 in LSE. By the time of Czechoslovakia I was already fairly anti-Soviet, though not as enthusiastically as others - there was a very common anti-Sovietism on the Left at that time and since. There were good reasons: its domination of Eastern Europe - obviously - over which many principled people had left the British Party after Hungary in 1956, but also its ambiguous role in Third World struggles. The Soviet Union was immensely important to that, but not in any principled way. We became increasingly aware of that during the Vietnam War as Soviet aid to the North was measured and qualified by other strategic interests. And then, of course, there was also the Cultural Revolution (GPCR) in China.

What was the attraction of Maoism? It seems so far removed from where you began - and where you ended up - with its emphasis on the peasantry as the revolutionary subject.

Well I think it was not just the size of China but its extraordinary revolutionary history, which always captured my imagination and my sympathy. I had read all those classic journalistic accounts from the 1930s and 1940s about the Long March, and the revolution more widely, which were on my parents' bookshelves. That was epic, and perhaps somewhat romantic too on my part. And then there was the possibility that here is a pole of international importance, providing an alternative to the Soviet Union that spoke to the Third World, and also the proletarian revolution itself - the Maoist claim that the tremendously disruptive mobilization of the GPCR was launched to save and/or recreate the revolution. So it seemed to be the antithesis of the standard story of the Soviet Union with its Stalinism, bureaucratization and the marginalization of mass politics. This was not to write a blank cheque for the Cultural Revolution, but reflected a sense of its importance and an attraction to what we were told or promised it was about. I did not have the reaction that seasoned Trotskyists had. Someone like Bensaïd was completely opposed: for him this was another version of Stalinism, at least that's 
what he said in his memoirs (Bensaïd 2013). New Left Review at the time had its own tensions over Maoism and the Third World. And for French thought which we followed Maoism seemed to be an influence on more important critical and even deviant thinking: Althusser, Foucault. I suppose for me it was also real curiosity and perhaps an openness to Third Worldism without buying into it uncritically. The whole history of Latin America and Africa and Asia was massively important and, with few exceptions, was not widely or deeply considered by the European left until the 1960s.

Regarding peasantry, I had already read Barrington Moore (1966), a very influential text, and also Hobsbawn on Primitive Rebels (1965). But it was only later, in the 1970s, that debates about the peasantry, and its politics, really took off. What still interested me most was the Party as the vanguard of the revolution. I suppose I still had traces of a Leninist formation (which I retain to this day?!): who organizes the revolution? Not just who creates it. Of course China has this long and incredibly dynamic history of peasant wars anyway. But my turn to the peasantry, at least in an intellectual sense, came about in Tanzania. In Britain at the time, the interest rather was in what was happening in the trade unions. In the most militant unions the Communist Party had a disproportionate influence: disproportionate to its size or its importance in other arenas like electoral politics. I was very interested in what was going on in trade unions and work place and other union struggles in Britain. That was my reference point. It was not that I threw all that overboard because of some new romance of the peasantry. I don't think I ever had a romance of the peasantry actually.

After leaving the LSE, you began your academic career in the emerging field of Development Studies. How did this come about, and what were the first teaching positions that you held? When I was finishing my Master's degree at LSE, I was offered a post in Sociology at the new University of the South Pacific in Fiji. There was no follow-up and it finally turned out that I was refused a work permit because of my (now lapsed) Communist Party membership. Fiji was still a British colony being 'prepared' for independence and Special Branch was looking after its 'security'! Instead I got a short-term job as a Research Assistant at IDS, Sussex, in 1969.

Dudley Seers was still the Director of IDS at that time and someone I respected, a principled social democrat, very important to the whole progressive structure of Development Economics from the 1950s. IDS ran six-week study seminars for civil servants from developing countries, and a proposeal for one on nationalization was accepted and advertised. This reached the British Parliament. Various Tory MPs said that British taxpayers' money cannot be used to 
tell 'our coloured cousins' how to nationalize mines and all that. So there was a fight in the IDS and the seminar went ahead but without government funding. I was involved and wrote an account of the struggle, published in a Penguin book on what was happening in British universities, something of a last gasp of 1968 (Bernstein 1972a). Dudley Seers was apparently very upset by my piece, though it was not ad hominem,

From Sussex I went to the University of Kent in Canterbury in 1970, in the period of massive expansion in British universities. Kent was setting up a new programme of 'interdisciplinary studies' in Social Science and I got the post in Development. I was attached to the Sociology and Anthropology department, and we had two years to design the courses. I did some teaching in the first year in Sociology and in the second year I got an invitation to go to Turkey.

\section{These were turbulent years in Turkey, how did it work out?}

The invitation was for a visiting teaching appointment in Sociology at the Middle East Technical University (METU) in Ankara, and came through Mübeccel Kıray. The military coup took place in 1971 just before we left for Turkey, and when we arrived Mübeccel had gone into hiding. Deniz Kandiyoti - who I had known at LSE - and her husband met us and made sure we had a roof over our heads. The university was also closed so Renee and I spent the first month or two travelling around Turkey by bus with the kids. We were the only western Europeans travelling in buses, other than hippies.

When the university reopened, I began teaching comparative Sociology. Ankara was still under martial law. Indeed one of the main armed Left groups in Turkey had come from the University I was at, and several of them were executed while we were there. It was impossible to talk openly about Marx in the class room, but there were ways around that. I made a number of good friends among students who are now Professors and Deans in Turkey in the Social Sciences, some Marxist some non-Marxist, and one a prominent social democratic public intellectual and leading critic of the regime's increasing authoritarianism. One or two had alignments with underground leftist groups, but the majority I interacted with were simply intellectually curious with progressive instincts. I retain close contacts with some of them. I also did a lot of informal teaching. We got together in our flat. There were no set readings: students would come along with issues they wanted to discuss - and then leave before the curfew started.

At the end I had to stay two months to finish my contract although there was no teaching and I made some interesting travels by bus and hitch-hiking. On the one hand, there is this great 
generosity and hospitality in Turkish culture, on the other hand, certainly in those days, an authoritarian and very patriarchal side. There was some fantastic cinema by Turkish Left filmmakers featuring social realities that they presented, in effect, as 'feudal' ('eastern') primitivism. Family life, religion, patriarchy, the plight of women, the treatment of Kurdish migrant workers, the cruelty of institutions including the prisons where many people ended up.

\section{How was it when you returned to the University of Kent?}

Canterbury was a whole new thing and I made important friends there. There was a strong and diverse group of the Left among younger staff and strong branches of both the International Socialists (IS) and International Marxist Group (IMG), with a lot of activism in and around the campus. Vietnam was still a focus and one mobilization was blocking off the campus to prevent E.V. Rostow (W.W.'s brother), a former senior member of the US State Department, from coming to speak. There were campus issues, occupations, local issues, anti-racism and making connections with the Kent miners. Interesting people came to talk on campus, and then hang out, including Lawrence Daly, the Scottish miner's leader. I also had a budget to invite people to come and give talks to my undergraduates. During that period I brought Mübeccel Kiray, Lionel Cliffe, Peter Lawrence, Ernesto Laclau, Terry Byres, the first time I met Terry who became so important to me.

Those years at Kent were key for several reasons: I was learning how to teach; I had all these interesting visiting speakers who used to come and often stay overnight at our house; and Renee and I had a group of friends who were graduate students from Iran, Palestine, and Turkey. We were very close, shared long and intense conversations, and had a regular monthly dinner together. It was great, a really vibrant period.

This was also the period in which you began to publish on development theory. What was the state of Development Studies then, and with what issues were you engaging?

It was at a relatively early stage of its formation as a professional field. IDS was in the forefront of the new Development Studies addressing a lot of macro-policy issues, trade, planning and so on, in which Dudley Seers was very important, of course. There was a lot of interest in how states worked and how they could be more efficient. There were several places in British universities which had a kind of hangover or continuity of the developmentalist phase of late colonialism, of training civil servants. But this was before the big upsurge in Development Studies as a degree subject and the formation of new departments to teach it, which happened subsequently. I remember a few meetings of the British Sociological Association in the early 
1970s which had a group working on Development, mostly made up of people on the Left, committed anti-imperialists. The first time I met Harold Wolpe was at one of those meetings. Dependency theory was also very strong at the time. But I didn't regard this as 'Development Studies' in the more current institutional sense. I was teaching the Third World. I divided my students into three seminar groups: one on Latin America, one on Africa and one on India. During that time I was reasonably up to speed with the literature coming out on the three worlds as they called it in French. It was wonderful to be that age and have that energy.

Associated with the Kent position was a series of Penguin Readers. I edited one on Underdevelopment and Development with an introduction that interrogated the idea of ‘interdisciplinarity' (Bernstein 1973). My main line was that you do not get interdisciplinarity by lumping disciplines together; you actually need a theoretical framework that is intrinsically capable of linking the economic, the social and the political. For me that was Marxism. Dependency theory was then the stick used to beat modernization theory, and in the Penguin book I included several Latin American theorists who I thought were better than many of their followers in the North. In fact, my Master's thesis at LSE had been a critique of modernization theory. That was my first published article in which I was encouraged by Donal Cruise O'Brien, who had supervised me from SOAS (Bernstein 1971). In later years, it became clearer to me that one basis of his antipathy to modernization theory was his disdain for liberal do-gooders. He was a total believer in realpolitik. But he was a good friend to me when I was a Master's student and afterwards. It was only later in the 1970s that I became more clearly disabused of dependency theory and the experience of four years in Tanzania was crucial to that. (At the end of the 1970s I wrote a piece that was critical of both modernization and dependency theory (Bernstein 1979).) The Journal of Peasant Studies had also just started in the early seventies (1973), and I was very interested in it. I published a review article on West Indian plantations in the first volume (Bernstein and Pitt, 1974), but it was our move to Tanzania in 1974 that stimulated my own work on the peasantry.

This was a legendary time at the University of Dar es Salaam (UDSM). How did you get to go there and what was the atmosphere like?

I got an invitation to teach at UDSM. The prospect of going to sub-Saharan Africa was very exciting. I had been reading Issa Shivji (1972, 1973), had already met Mahmood Mamdani, and was aware of the Dar es Salaam debates. ${ }^{2}$ I was aware of the Dar aura, you might say. We

\footnotetext{
${ }^{2}$ For summaries of the early debates see the two volume collection edited by Cliffe and Saul (1972, 1973).
} 
initially went there for two years and wanted to stay longer but Kent would not allow that (I was on two years' leave), so I resigned and we stayed in Tanzania for four years.

We arrived at a very interesting moment. Walter Rodney had just gone back to Guyana, where he was murdered a few years later; Clive Thomas, another Guyanese, had left, as had other famous expatriate teachers at UDSM - Lionel Cliffe was in Zambia by then, and John Saul had gone back to Canada. But there was still an extremely dynamic intellectual community of the Left. It was very cosmopolitan, people from other African countries, exiles form South Africa and Zimbabwe, people from the Caribbean, some really interesting maverick Left characters from Eastern Europe, Germany, the US. New debates were also being set up, particularly by the East African comrades. There were Shivji and Mamdani and then another group of Ugandan exiles led by Dan Nabudere and Yash Tandon who were involved in a bitter feud with them. It was a febrile atmosphere with a lot of immediate political issues: the liberation struggles were still going on in Southern Africa. The Maoists tended to be anti-ANC, anti-Frelimo, anti-MPLA - if the Russians were supporting anyone, they would not. So, if you were new to the scene it could be kind of intimidating. More than once Mamdani and I had to defend comrades' right to speak and be listened to with respect, however much we may have disagreed with them.

I made some important intellectual friends who were often personal friends as well. There was JACques Depelchin from the Congo via Stanford, and we became very close. There was Marc Wuyts in Economics, Mahmood Mamdani, and Dan O’Meara, an outstanding historian of South Africa. And the DSM aura attracted many visitors. The first time I met Jairus (Banaji) was in Dar es Salaam, Hamza Alavi and Biplab Das Gupta came through. Harold Wolpe and Ruth First both had visiting teaching appointments; Joe Slovo came to town on ANC business. Dar es Salaam was an exceptional place. Renee was teaching at the international school where our kids went. At speech days and other events they would have speakers from Frelimo, the PLO, ANC. This was kind of unusual for an international school!

And there was also a very tight community on the campus, a lot of friends and kids all friendly with each other. By the late 1970s, things were getting serious with Nyerere resisting the World Bank, plus self-inflicted wounds like villagization, which I witnessed in rural areas - a very miserable sight. Subsequently, the state began to clamp down on the university. These were also tough times economically. Tanzanian academics had to do other things to get by, getting into business and so on. Many became consultants, which diverted their energies and talents away from doing proper research. 
You mentioned before that it was in Tanzania that you settled your debts with Dependency Theory. Before we discuss your forays into African agrarian political economy, would it be right to characterize this as a time of self-clarification around more general questions of development and underdevelopment?

I really can't overstate the importance of Dar es Salaam for pulling together and focusing some of the things that I'd been thinking beforehand, and for everything that I did subsequently. I probably was already sceptical about populism, which was reinforced by the four years in Dar. I witnessed first-hand, in situ in a Third World country, the easy seductions of nationalism, the so-called 'Marxism' that was actually nationalist-inspired and amounted to little more than 'anti-imperialist' rhetoric. It was formative in so many ways. One crucial engagement for me was with Geoffrey Kay's Development and Underdevelopment on which I wrote a review essay (Bernstein 1976). There wasn't anything in his Marxist argument that gave support to dependency or Third Worldist positions dominant at the time. Its notorious phrase was 'the problem with the Third World is not that it was exploited but that it wasn't exploited enough'. That linked to his whole analysis, also grounded in his work on Ghana, of merchant capital as central to the colonial capitalist enterprise.

I also thought that a lot of the French articulation (of modes of production) literature was very important, even if I grew more sceptical of some of its positions during this period. It was written by people who were sophisticated Marxists theoretically and had done massive field work in West Africa, like P.P. Rey and Claude Meillassoux (who I later got to know personally). They were also politically committed, very involved in issues of African migrants in France, for example. I knew some French and did a summary translation of Meillassoux's (1975) book Femmes, greniers et capitaux (Maidens, meal and money) for comrades at UDSM and spent a lot of time discussing it, and much else, with JACques (Depelchin) who was a French speaker. It became fashionable a bit later to trash articulation; there was Aidan FosterCarter's (1978) article in the New Left Review, and other papers in the US. But to me these critiques seemed to be very mechanical in a way. Although the overall articulation approach was problematic, it was very fertile as well and was one of the sources that stimulated my own thinking about dynamics and patterns of commodification, along with writers like Walter Rodney and Robert Brenner, coming from such different directions geographically and historically as well as intellectually.

Something else in UDSM, characteristic of our intellectual culture there and which helped me when I came back to England jobless in 1978, is that we wrote papers to circulate for our own discussions. When we returned to the UK, I had a bunch of papers which were 
published in the Review of African Political Economy and Journal of Peasant Studies. I also wrote with JACques Depelchin a long quasi-Althusserian paper that later appeared in two parts in History in Africa (Bernstein and Depelchin 1978, 1979). At some point in the mid-1980s I was invited to a postgraduate African History course at Stanford to discuss the paper. I couldn't remember much about it and didn't even have a copy! When I managed to get one and read it, I remember my heart sinking. But I can think back to what JACques and I were trying to do and why, in the circumstances and conditions of the time, even if I wouldn't take the same approach now.

This then brings us to your own attempt to theorise the peasantry within Marxist political economy, which was to remain a lifelong preoccupation. How did this come about? ${ }^{3}$

A Tanzanian colleague, the late Henry Mapolu, and I decided to teach a two-year 'Introduction to Capital' in the second and third year of the undergraduate programme. That was very important: teaching Capital to students who had no first-hand experience of the kinds of dynamics and relations that Marx wrote about, while exposed to the kind of simple-minded 'anti-imperialism' peddled by Nabudere and others. This was a big challenge and we had to think very carefully about how to teach the course. One of the things I got from that, and which fed directly into my thinking, was that the forms of commodity relations our students had experienced were those of petty commodity production and exchange.

The other thing I realised very soon in teaching was that 98 per cent of my undergraduates came from rural backgrounds. I always used to talk to them about how things were back home when they went to visit. What they told me was fascinating, yet they would write essays for my courses on rural development that were so weak: 90 per cent about Julius Nyerere, how great Ujamaa is and how it was betrayed by bureaucrats. This evidently reflected how they had been taught, and the ideological ambience in Tanzania. I then pursued agrarian political economy, to think about ways of teaching them, encouraging them to reflect on their own experience in more analytical ways. I did papers on how to use Lenin when you go to your village, what sort of things you are looking for. Later I was instrumental in setting up an agrarian studies group with Marjorie Mbilinyi and Deborah Bryceson and met others like Phil Raikes and Jannik Boesen, people on the Left with a strong formation as researchers of agrarian

\footnotetext{
${ }^{3}$ In this part on Bernstein's theorisation of the peasantry we did not pursue a precise account of his concepts (or of Gibbon and Neocosmos' critique) but rather the context of things, how they came about and the problems and thinking behind them. More precise discussion and assessment of his theoretical frameworks can instead be found in Bridget O'Laughlin's article in this special issue and, of course, in Bernstein's own work which is detailed in the full bibliography at the end of this interview.
} 
change in East Africa and with a lot of field experience. It was terrific for me to learn from them. So that is how I really got into peasant studies, or why I got into it.

I also did village research in an area some 50 miles south of Dar es Salaam which was a very different social world. It was through this field experience and what I was learning from my students that I began to recognise the importance of having a more flexible, less dogmatic notion of what rural class differentiation means. I think it was there in Lenin, but had to be pulled out and illustrated in relation to Tanzania. Unlike many parts of Africa at that time, where investments in a small pickup-truck, say, or a bus would probably come from migrant labour earnings, in Tanzania that investment was more likely to come from farming. There was not the same degree of migrant labour wages which might be remitted to support simple or expanded reproduction in the countryside. Once you had the means of transport or access to them you could start crop trading; you could start advancing credit against the crop before harvest. My students all knew these things were happening, and the pressures on reproduction faced by their parents, siblings and neighbours in their home villages, but they did not have a framework, a language, a way of seeing that it was actually a structured dynamic.

Perhaps one of the most important things I became aware of as I was thinking this through was that most of sub-Saharan Africa had very different circumstances from the classical agrarian question and transition as it had been transposed to places like Latin America or India, namely the lack of classes of landed property. I remember discussing this with Hamza Alavi, who was a friend and very supportive. Being from Pakistan, he could see the differences and their significance. If you study the peasantry in capitalism and pass beyond a more or less standardised 'colonialism exploited the peasantry' formulation, and there is no class of landed property which is the agency of their exploitation, then what sort of class dynamics are we talking about? I was particularly influenced in Dar by Jairus Banaji's article on 'Modes of production in a materialist conception of history' (1977), and spent two years reading and rereading it, trying to make sense of it. ${ }^{4}$ For a time, I was hooked into his notion of peasants as wage-labour equivalents, subject to formal subsumption by capital. That enabled me to think about peasantries in Africa within capitalism, without resting on the assumption - in much of the Latin American literature, the European historical literature, and the Indian literature - that they were subordinated to a class of landed property of feudal origin or provenance.

\footnotetext{
${ }^{4}$ An engagement that is ongoing: see Bernstein's (2013a) review of Banaji's (2010) Theory as History, and Banaji's (2013) response.
} 
Another thing I remember thinking about a lot, partly in relation to Banaji's work but also more generally, is the relationship between form and content. It's obvious that similar forms may have a different content in a materialist approach, but the form has a consequence. And the fact that a shared, similar content can exist in, say, both form a and form b actually has consequences too, not least consequences for how people experience social relations, which feeds into consciousness and informs their practices. In Tanzania, this was particularly apparent in the way that experiences and notions of peasant 'community' subsumed dynamics of differentiation. It might seem obvious to us, but the idea of class differentiation is not so easy to put across in a way that people might pick up and use because - and this comes up as an issue in the Via Campesina type of populism - although it is understood that there are these people in the village who are better off than us, they are just a little better off, and are still part of 'us'. Then there is the folk wisdom in many peasant areas, born of experience of course, against the outsider, be it the tax collector, the government official, the person doing the cadastral survey, the merchants, the governor, the state! So we sink our differences and we are all in the same boat, uniformly experiencing our 'exploitation' as 'the people', which finds its expression in policies like Ujaama. And of course in agrarian change within capitalism you get this extraordinary diversity of forms. One of the things that I appreciated later on was some of the political economy literature on informal economy and its investigations of diverse forms. I am not an expert on Marx's method, but I was alert to methodological issues and studied them with interest. When I read people I admire who write about method like Jairus, even if I don't always agree with him, it helps me understand, it helps point me in a certain direction.

The articles that came out of this period had an enormous impact on African agrarian political economy, but then in 1983 your position on the peasantry was subjected to a though-going critique by Peter Gibbon and Michael Neocosmos. This was actually published in a book that you co-edited (with Bonnie Campbell) and was subsequently incorporated into your own work. ${ }^{5}$ Can you tell us about that?

The Gibbon and Neocosmos article had a massive impact on me, I didn't agree with everything they said but I learned from it. I didn't felt threatened by it. I don't think I ever felt threatened by any sort of constructive critique that carried my thinking forward. Some of my comrades thought that Gibbon and Neocosmos were too orthodox in how they used certain parts of Capital; they also objected to the notion of a 'simple reproduction squeeze' which I still think

\footnotetext{
${ }^{5}$ Gibbon and Neocosmos 1985; Bernstein 1988.
} 
is a useful notion. But their intervention helped me to think further about how to analyse the peasantry in capitalism without necessarily being some in quasi-feudal relationship with landed property, and especially how commodification is internalized in the workings of peasant households, through relations of gender, generation and so on. That was a key step. It wasn't there before in the wage-labour equivalent notion, Jairus's view of the formal subsumption of the peasantry. Gibbon and Neocosmos helped me clarify that.

Another extremely important moment during that period was when I joined Terry (Byres) in editing JPS (Journal of Peasant Studies) from 1985. First of all, we began to get early feminist analyses, but there were no women on the board and we had to address that. ${ }^{6}$ Someone else I became friends with when I came back from Tanzania and whose brilliant work I greatly admired was Harriet Friedmann. She was already talking about global capitalist economy and I remember saying to someone at JPS that we have to push ourselves further and reach out to this new analysis of world economy and agrarian change, you know, world markets, agribusiness corporation, commodity chains, and so on. I suppose this came up again later in my comradely critique of Terry's book and raising the question of how adequately an 'internalist' problematic applied to earlier periods and trajectories of capitalist development (Bernsetin 1996a). ${ }^{7}$ When Terry and I started this Journal in 2001 we took the opportunity to write an extensive survey of work in agrarian political economy over the previous 30 years.

After Tanzania you moved back to Britain and worked at The Open University (Lecturer in Third World Studies 1980-85) and then Wye College, University of London (Director of the External Programme, 1985-89) - in both cases on innovative distance learning programmes. What role do you see pedagogy playing in your academic career as a whole?

I've always seen myself as a professional teacher more than anything else. I enjoyed very much working for the Open University in a course team which produced valuable teaching and learning materials that were used in a range of contexts, and also contained some substantive innovations, for example, the idea of 'rural livelihoods' later taken up by Colin Murray (2002) and Ian Scoones (2015). I was struck by the care of its attention to how students learn. Writing OU texts puts a premium on clarity, accessibility and organization, from which I benefitted when I later wrote my little book on Class Dynamics of Agrarian Change (Bernstein 2010b). I think I already had something of that because I had spent some years teaching people whose

\footnotetext{
${ }^{6}$ See Bernstein and Byres' (2001) reflection on the Journal of Peasant Studies and the changing field of agrarian studies in the first issue of Journal of Agrarian Change.

${ }^{7} \mathrm{~A}$ discussion that continues in the contribution of Byres to this volume.
} 
first language was not English and also people who did not have a social science background. The OU was committed to a far more democratic style of education than other British universities. It was fascinating to teach at its summer schools. We had a summer school during the miners' strike of 1985-6 (in which I was active in the Kent coalfield), with classes that included both striking miners and cops! And who were prepared to debate. There was nowhere else in the UK in the 1980s where that applied.

In the wider context of the time, the British Left, or most of it, was completely wrong footed because we had been so enthusiastically engaged in a critique of welfare capitalism in the 1960s - critiques of the NHS, of the education system, sometimes linking up with more culturalist critique and elements of anarchism: who is really controlling public services and so on. And then Thatcher comes along! We were not well-equipped for that switch from critiquing to defending these public services. Thatcher showed that some of the pillars of the Keynesian social democratic welfare state and its bases of support, like the trade unions, were flimsier than most of the Left supposed. You know: 'The NHS is not democratic'; 'Social welfare services oppress poor people'; 'The education system is not delivering an open, expansive education to the working class'. All these things were true, but then suddenly all that is under massive attack. 'Nationalized industries are not democratically controlled by their workers' well a few years later there were no nationalized industries left, so it was a deeply depressing moment. Although purely at a subjective level I don't know if it was depressing as the Blair years and now.

The time at the OU was also when I felt somewhat removed from what was happening in Africa, or at least removed from being able to comment very usefully on it, until structural adjustment picked up in the 1980s and I wanted to say something about it (Bernstein 1989, 1990). This was a strong signal of gathering neoliberalism applied ruthlessly to one of the poorest areas of the world.

My apprenticeship in distance education at the OU led me on to Wye College, the then agricultural school of the University of London, where I was responsible for designing and delivering the university's first degree by distance education. The university had long had an external examining facility, which from the colonial period examined and validated degrees around the world, but they had never put on fully-fledged distance education with customdesigned materials. It was a quite a stretch but worthwhile. Our distance education project was a cottage industry; we didn't have the support and production systems of the OU, so had to invent that on a shoe-string as we went along. I think I achieved something there. And by joining Terry in editing the JPS from 1985 I also maintained contact with comrades working 
in agrarian studies all over the world, which was a major lifeline while I was at Wye. Otherwise I might not have kept that interest alive.

Pedagogy is equipping people to think for themselves, to think critically, encouraging them to do so, but not to tell them what to think, which is entirely wrong. That runs through my own pedagogy and is the general ethos of the Open University. Distance learning materials are also in the public domain which is a very good discipline. I could bring Marx and Lenin into student texts without saying that you have to believe them like gospel, but bringing to the students' attention that there were these people, located in particular historical moments with particular preoccupations and questions, who generated ideas that transcended their times and places.

The OU syllabus and materials had a significant impact in shaping how Development Studies was understood in Britain during the 1980s and 1990s. What are your thoughts on the development of the discipline?

Development Studies is not a 'discipline' in my view. It has now become so encompassing that everything and anything can be included in it. From my ideological point of view there was a more golden period of Development Studies, at least as intrinsically pluralist and a flag of convenience, but with the changes in British universities inflicted by neoliberalism, and managerialism, I think much of the shine has gone off it.

I avoided commenting on Development Studies until Uma Kothari persuaded me to write for her book (Bernstein 2005). Perhaps I was ready at that point. For Uma's book, I had a question in my mind: 'what does Marxism in Development Studies mean?' If you are talking about understanding the world economy and its class dynamics, Marxism of course is central. But if you are talking about Development Studies as policies to overcome poverty and to better manage national economies and the rest of it, I didn't know if there is anything specific or intrinsic to Marxism there. I asked Ben Fine, Terry Byres and John Weeks about this and I didn't really get an answer beyond progressive structural economics.

In a recent book my former PhD student Ben Selwyn (2014) puts forward the idea of 'labour-centred development' versus 'statist' conceptions of development. It is true, as Ben says, that the latter are at the core of much Development Studies, but I have two questions about his argument. First, isn't it necessary to distinguish among the variety of statist development policies and practices those that have been (much) more pro-labour? And, second, is it possible to imagine 'labour-centred development' without a strong and effective state? 
In terms of statist macroeconomic policies. I think in a roundabout way we get back to square one, to my initial question. Even when I asked my economist comrades about debates in the Soviet Union, which I knew about, I couldn't see what was intrinsically Marxist in them, other than attempts to find effective policies for accumulation and maybe, to a certain degree, of distribution within a certain political context - in short, the same preoccupations as progressive structuralist economics, albeit a very long way from neoliberalism.

Subsequently I wrote several somewhat more polemical pieces about what Development Studies had become in the neoliberal moment. I was stoked on by Bill Freund who was involved in Development Studies in Durban, and who used to say 'teaching 19-yearold students how to overcome world poverty: is that serious?'

I try not to be judgemental about the relationship between academic production and more policy focused work, even though it's not my thing. But I have great respect for what Ben Cousins has done in South Africa, to address and try to enlighten policy debates over land reform - an uphill task, for sure. And Jun Borras who tries to tread some very fine lines between academic work and activism, and activism and policy institutions like the FAO. I don't take an ultra-leftist position, that all policy-engagement is selling out or a waste of time. I suppose the message in what I've written is that you can do many things, but don't delude yourself that you are doing more than you are doing. This is my main concern, because of the absolute awfulness of mainstream ideology, whether in the multilateral institutions, global institutions, bilateral donors or many NGOs and its syndrome of feeling good about doing good. The point is if you want to feel good about what you do, you have to earn that, don't take some sort of secondhand ideological clothing off the peg: 'I am trying to help the poor'; 'I'm trying to push the World Bank a few inches more in a progressive direction'. The most significant scholar of my generation in Development Studies in Britain, in my opinion, is Barbara Harris-White who has extraordinary intellectual range and strength. She follows closely and comments very clearly on policy debates, with such a clear eye on the savage inequalities of class, gender and caste, and without any of the self-delusion so rampant in 'applied' work..

I suppose part of my view of Development Studies is that for all its contradictions and limits, it can be - depending on quite specific and favourable circumstances, which are far fewer than in the past - a convenient banner or flag to do different things. SOAS has a remarkable Development Studies department, probably the most heterodox in Europe, that, together with its sister (half-sister?!) Economics department has achieved an impressive measure of generational reproduction in critical political economy. Of course, three of the five editors of this Journal are based at SOAS and another is a SOAS PhD graduate. And there are 
some younger scholars elsewhere doing remarkable materialist work, and contributing to this Journal and the Journal of Peasant Studies.

In the article in Bill Freund's Festschrift which was called 'Studying development/development studies' (Bernstein 2006) I said studying development in the broad sense is at the centre of modern social sciences. But it also means that a lot that is relevant in that more positive and inclusive sense is being done outside of Development Studies, inevitably: departments of Economics, depending on how lucky or unlucky you are; Anthropology; History; even Business Schools!

It seems that from the early 1990s, you began to reengage with agrarian issues, returning to older themes but also setting out in new directions. To conclude the interview, it would be interesting if we could explore some of these, and also your thoughts on how agrarian political economy has developed as a field in the years since the launch of this Journal. A good place to begin chronologically is with the body of work that you produced on South Africa between 1994 and the mid-2000s. What stimulated this and what were your main concerns?

Well I was always interested in the struggle in South Africa, and knew Harold Wolpe and Ruth First among others. I was interested in the politics of it and the debates within the liberation movement. I had the opportunity to go there for the first time just after the unbanning of the ANC and SACP in 1990. I had actually been invited before but declined as there was an embargo by the ANC and my own trade union. In 1990 or 1991, Michael Neocosmos asked me to Lesotho as an external examiner in Sociology. When I went, I met Richard Levin who was in exile there with various other comrades Crossing the Lesotho-South Africa border was a stomach-churning experience of what apartheid looked like. There was barbed wire everywhere and heavily armed South African troops, with long lines of black Southern Africans waiting to get through.

I met Mike Morris and Bill Freund in Durban who said, 'we have this fellowship, why don't you apply?' I had to come up with something quickly and I thought about research on maize. I had been working with some French filière people in Montpellier, among them Alain Leplaideur, Paule Moustier and Hélène Benz. I didn't know well the commodity chains literature, so just took off from what I learned from them and devised my own home-grown filière approach. (Later I wrote, with Liam Campling, a more systematic essay on some of the agricultural commodity chains literature.) I thought: 'most marketed maize is produced by a small number of big (white) farmers in South Africa as the staple food of the (black) working class, so let's see how this works'. And that's what I did in my five months there. Some of this 
was published in a special issue of JPS on the Agrarian Question in South Africa, which I edited in 1996. The first part of that paper is a kind of thinking out loud - how I got to what I was doing with the maize filière. I also became interested in the debates around land reform in South Africa and wrote a conference paper that was not published but which was cited quite a lot. I got to meet Ben Cousins in the early 1990s when he was just returning from exile in Zimbabwe and moving towards setting up PLAAS, which had its 20th anniversary in $2015 .{ }^{8}$

I was able to go back to South Africa reasonably often in the 1990s and keep in touch with events there. I did some policy work with Nick Amin on agricultural cooperatives for the ANC's Land and Agricultural Policy Centre (LAPC). This built on the work I did on the maize filière and I think we really put our finger on something (Amin and Bernstein 1996). I have only done two periods of what might be graced with the name fieldwork, one of which was in Tanzania in the 1970s and the other was the research on maize and the big maize coops in South Africa from 1992 to 1996. Although Nick and I did not have any illusions about the possibilities of policy changes in the new dispensation, it was still a salutary lesson. The LAPC organised a 'stakeholders meeting' to discuss the draft report, which had a working title of 'Agricultural Cooperatives after Apartheid', or something like that. So these officials came along from all the major coops, which are big agribusiness by any other name, and said, 'well, the first thing you do is remove apartheid from the title of the report because we are just farmers and businessmen; we are not political; we have nothing to do with apartheid...'!

There was very little on the Left about agriculture in South Africa at that time. The main contribution was Tessa Marcus' book Modernising super-exploitation: Restructuring South African agriculture, otherwise the Left literature was historical or about the Bantustans. And really it was quite a difficult moment, one of the reasons being - as I remark in various papers - that the ANC had no position on land and agrarian reform whatsoever. It recruited people to the new Department of Land Affairs whose hearts were in the right place, but whose minds (and politics) were mostly not up to the task - a kind of mixture of NGOs, Land Committee type people, foreign consultants and so on, with the World Bank looking over their shoulders. It is well known that Derek Hanekom (the first Minister of Land Affairs in the 1994 government) got his fingers burned because of all that. It was a mini-disaster in the context of a bigger reversal, because the Reconstruction and Development Programme (RDP), and the

\footnotetext{
${ }^{8}$ Founded in 1995 at the University of the Western Cape, PLAAS was initially called Programme for Land and Agrarian Studies, and is now the Institute for Poverty, Land and Agrarian Studies, but with the same acronym.
} 
hopes invested in it as a COSATU-Communist Party-(Left) ANC initiative came to nothing, as did the macroeconomic plan by MERG (Macro Economic Research Group). ${ }^{9}$

To what extent has looking more at ecology, the environment and the productive forces changed the way that you think?

I think it has. I think it has to for any materialist but I've had to undergo some self-education, still incomplete despite help from friends who trained as natural scientists, like David Wield in UDSM and the OU, Peter Mollinga, and Philip Woodhouse with whom I worked at Manchester in-between Wye and SOAS. The little I have written on this are commentaries rather than substantive contributions.

In the introduction to the ecology special of this Journal I noted problems in the Marxist tradition, to do with nineteenth century progressivism, the conquest and subordination of nature it assumes or proclaims, and its legacies (Bernstein 2010a). That the Left needs to be equipped intellectually on the grounds of an ecologically based or informed Marxism is indisputable, it seems to me, and that is why I have been so excited, if not wholly convinced, by Jason Moore's remarkable project on capitalism as 'world-ecology'. We are faced with a situation, which I have mentioned in various places, where populism is making all the running on this: world agriculture's ecological destructiveness and the 'peasant way' as the (only) path of progress. To me it is not adequate to respond by saying we disavow populism, end of story. It may have false solutions but some of the problems it highlights are real enough.

You have continued to engage with agrarian populism in recent years, including on new terrain such as food sovereignty. Who are some key figures for you here and what are the crucial areas of debate?

'Key figures' has a nice ambiguity: does it mean those who make the most noise? Or does it mean those who advance the terms of debate between materialist and populist approaches? I prefer to answer the latter question, and they include for me Jan Douwe van der Ploeg because he knows a lot about what farmers do, based on field work in many different places. And my friend Jun Borras, also mentioned earlier and now editor of JPS, also forces me to consider and engage with populist ideas at the meeting point of academic work and activist discourse and practice. It was Jun who talked me into writing about food sovereignty, which I did with as much analytical care as I could. This did not prevent an onslaught on what I wrote from the

\footnotetext{
${ }^{9}$ See the recent reflections on MERG in Freund (2013)
} 
usual 'friends of the people' which points to a classic problem: their view that because you don't accept their 'solution' - one or other version of 'the peasant way' - then you must lack all sympathy and solidarity with those classes in the countryside which are being hammered by the onslaughts of contemporary capitalism. I am able to engage better with others of more serious intellectual calibre who align themselves with La Via Campesina, and I try to do so.

At the same time, I urge them to consider the question: Who do we think are the workers? My notion of 'classes of labour' is only a kind of shorthand for dynamics of class formation that the work of others has explored, for example, Jairus Banaji, Jan Breman, Barbara Harris-White, Jens Lerche and Marcel van den Linden, and taken up by Jonathan Pattenden (2016), another SOAS PhD graduate, in his important forthcoming book. They are illuminating the historical moment we inhabit which, in such important respects, departs from our conceptions of agrarian questions inherited from the nineteenth century and the first half of the twentieth century. I should note here too the SOAS-centred group that works on 'rural wage employment', meaning both wage employment in agriculture and the role of wages from non-agricultural work in rural reproduction, not least from labour migration (Oya and Pontara 2015).

However, I don't have an answer to the question of what is the alternative to the Via Campesina position, which clearly has a simplicity and coherence as an ideological platform, and an attractiveness to many on the Left. There is no recognized Marxist position on agriculture and its future now, if ever there was; no recognized or widely accepted socialist country that provides some sort of 'model'. One can look at debates within the few socialist parties or movements that still exist, say the CPI-M in India. Some of its agrarian intellectuals have become populists; others - probably the majority - are holding to a class line but they are not very clear where that takes them in programmatic terms. What are the slogans to mobilize CPI-M support around agrarian issues, around issues in the countryside? So it is very challenging, especially if you reject a Warrenite perspective on one hand, a populist position on the other hand. Are those the only 'alternatives' on offer?!

Since 2009 you've been an Adjunct Professor at the College of Humanities and Development, China Agricultural University (CAU) in Beijing. Can you tell us a little about this experience and whether it has shaped your thinking at all?

I've been teaching there for seven or eight years, thanks to the rather special milieu, and project, created by Ye Jingzhong in the College of Humanities and Development at CAU. I haven't done field work, but it has encouraged me to read and learn about China again, on which I'd 
read a lot in the past. I got to know a group of young Chinese PhD students and Postdocs in Beijing, who I engaged with a lot, hung out with, had great conversations, and listened to their views of the world and so on. But they're mostly gone from Beijing, having graduated and moved to jobs in other universities; I missed them when I was last in Beijing. However, I have been fortunate to connect with other Chinese scholars outside the PRC, including some of the Chinese 'New Left', so-called, and finally felt confident enough to write and publish some views on agrarian change in China (Bernstein 2015a, 2015b). This was good as it took me somewhat outside my comfort zones (as did my recent writing on food sovereignty and the food regimes approach). Contemporary China presents such radically different historical and social conditions to those of 'classic' agrarian questions, yet is also amenable to investigation and explanation by proper use of some of the 'classic' ideas and methods, as the recent special issue of this Journal on China showed (Oya et al. 2015).

When you and Terry Byres launched the Journal of Agrarian Change you gave a very succinct definition of what agrarian political economy is. How has the Journal and Journal of Peasant Studies defined the terms of the field? And what are your reflections of the field today compared to when you started working with Terry on the Journal in 1985?

Terry can be credited with having carved out as a whole area of study and ways of studying it. He wrote a very nice article in JAC about how the Peasants' Seminar he established led to the Journal of Peasant Studies (Byres 2001); it is an extremely informative piece of intellectual history of great interest to all who work in agrarian studies. As we all do, Terry drew on sources, traditions, areas that he knew well and cared about. He was closely engaged with India, of course, and the Indian debates in agrarian political economy informed by Marx and Lenin and the European transitions they addressed. But I think also the agenda was developing without necessarily being consciously shaped or having an explicit charter, if you like. One example was the impact of feminism, which may have been slow to register in JPS but gradually became more and more important in JPS and JAC, and to which Bridget O'Laughlin made such signal contributions. Another was the debates about petty commodity production which began to connect issues of 'family' farming in the Third World and the North, and indeed agricultural and non-agricultural branches of petty production in capitalism. A third, also increasingly important over time, especially from the 1990s, was agrarian questions beyond national boundaries. (I think Harriet Friedmann and Phil McMichael's seminal article was published in 1989.) The world systems and food regime scholars expanded the agenda of agrarian political economy, bringing in changing patterns of international finance, changing 
divisions of labour, world markets and what drives them, and so on. And the best of them also enriched that agenda.

The 'mission statement' we came up with for JAC, in the line of JPS in its first three decades or so, is to promote 'investigation of the social relations and dynamics of production, property and power in agrarian formations and their processes of change, both historical and contemporary.' This has a coherence derived from a commitment to materialist political economy, which continues to inform $J A C$ under the leadership of the editors who replaced Terry and me in 2008. JPS, now led by Jun Borras and the stellar team he has recruited, has become more of a journal of political sociology and is more connected with activist concerns, although much of what they publish is political economy or is relevant to it, for example on financialization and international investment and trade

There are good relations between the two journals, as there should be, with a number of scholars from different generations contributing to both. The most important point for me is that each intellectual and political generation has its own concerns and devises its own approaches to them; the current generation can not, and should not, simply reproduce its predecessors. How could they when the ways in which capitalism changes, how the agrarian questions of today are constituted, how the contradictions and their effects shift, not least forms of rural-urban connections, are such central challenges? At the same time, meeting those challenges is the more effective from a strong grounding in the prior histories of capitalism, in all their diversity, and knowledge of the ideas about them that previous generations produced. That historical approach and knowledge remains central to $J A C$, and is all the more important at a time when it seems that for many capitalism only appears in the world with 'globalisation' or 'neoliberalism'. This may partly reflect their growing up in a period when state 'socialism' no longer exists, nor 'models' of socialist agricultural development, for better or worse. It can be too easy to reduce capitalism to an encompassing 'modernity' rooted in destructive industrialism - hence paradoxically a kind of technological determinism - rather than a distinctive, indeed unique, type of class society. It is the commitment to analysis of class dynamics that distinguishes materialist agrarian political economy from other forms of radical or critical social science. To be effective, that commitment requires embracing and striving to understand the great complexities of class formation and action, in all their concrete variation, in the countrysides of today's capitalist world.

\section{References}


Banaji, J., 1977. 'Modes of Production in a Materialist Conception of History'. Capital and Class, 1 (3): 1-44.

Banaji, J., 2010. Theory as History: Essays on Modes of Production and Exploitation. Leiden: Brill

Banaji, J. 2014. 'Putting Theory to Work'. In Debating Modes of Production and Forms of Exploitation, ed. L. Campling, symposium of Historical Materialism, 21(4): 129-143

Bensaïd. D., 2013. An Impatient Life. A Memoir, (trans. D. Fernbach), London: Verso Harman, C., 1998. The Fire Last Time: 1968 and After. London: Bookmarks

Byres, T.J., 2001. 'The Peasants Seminar of the University of London, 1972-1989: A Memoir'. Journal of Agrarian Change, 1(3): 343-388

Cliffe, L. and J. Saul eds., 1972. Socialism in Tanzania: An Interdisciplinary Reader: Vol.1 Politics. Nairobi: East African Publishing House.

Cliffe, L. and J. Saul eds., 1973. Socialism in Tanzania: An Interdisciplinary Reader: Vol.2 Policies. Nairobi: East African Publishing House.

Cowen, M.P. and R.W. Shenton, 1996. Doctrines of Development. London: Routledge

Foster-Carter, A., 1978. 'The Modes of Production Controversy'. New Left Review, I/107: 4777

Freund, B., 2013. 'Swimming against the tide: the Macro-Economic Research Group in the South African transition 1991-94'. Review of African Political Economy, 40(138): 519-536

Friedmann, H., and P. McMichael 1987. 'Agriculture and the state system: the rise and fall of national agricultures, 1870 to the present'. Sociologia Ruralis, 29 (2): 93-117

Gibbon P., and M. Neocosmos, 1985. 'Some problems in the Political Economy of "African Socialism"'. In Contradictions of Accumulation in Africa. Studies in Economy and State, eds. H. Bernstein and B.K. Campbell. Sage, Beverley Hills

Hobsbawm, E.J., 1965. Primitive Rebels. Studies in Archaic Forms of Social Movement in the 19th and 20th Centuries. New York: W. W. Norton \& Company

Kay., G. 1975. Development and Underdevelopment. A Marxist Analysis. London: Macmillan Meillassoux, C., 1975. Femmes, greniers et capitaux, Paris: Ed. Maspero

Moore, B., 1966. Social Origins of Dictatorship and Democracy. Lord and Peasant in the Making of the Modern World. Boston: Beacon Press

Moore, J.W., 2015. Capitalism in the Web of Life. Ecology and the Accumulation of Capital. London: Verso

Murray, C., 2002. 'Livelihoods research: transcending boundaries of time and space'. Journal of Southern African Studies, 28(3): 489-509 
Oya, C., and N. Pontara, eds., 2015. Rural Wage Employment in Developing Countries. Theory, Evidence and Policy. London: Routledge

Oya, C., J. Ye and Q.F. Zhang eds. 2015, Agrarian Change in Contemporary China, special issue of Journal of Agrarian Change, 15 (3): 299-477

Pattenden, J., 2016. Labour, state and society in rural India. A class-relational approach. Manchester: Manchester University Press

Scoones, I., 2015. Sustainable Livelihoods and Rural Development. Black Point NS: Fernwood Selwyn, B., 2014. The Global Development Crisis. Cambridge: Polity

Shivji, I., ed., 1972. The Silent Class Struggle. Dar es Salaam: Tanzania Publishing House Shivji, I., ed., 1973. Tourism and Socialist Development. Dar es Salaam: Tanzania Publishing House

Snow, E., 1937. Red Star over China. The Rise of the Red Army. London: Left Book Club Stories of the Long March. 1958. Peking: Foreign Languages Press Tausig, M.A., 1980. The Devil and Commodity Fetishism in South America. Chapel Hill: University of North Carolina Press

\section{Henry Bernstein's academic publications in chronological order}

The following lists published work by Henry Bernstein, including edited books and journal collections, working papers and reports, but excludes conference proceedings and distance learning materials.

1971. 'Modernisation theory and the sociological study of development', Journal of Development Studies 7(2), pp141-60

1972a. 'The Institute, the Ministry and the State Corporation'. In Counter Course. A Handbook for Course Criticism, ed. T. Pateman, 25-37. Harmondsworth: Penguin Books 1972b. 'Breakdowns of modernisation'. Journal of Development Studies, 8(2), pp 309-18 ed., 1973. Underdevelopment and Development. The Third World Today. Harmondsworth: Penguin Books 1974 (with M. Pitt). 'Plantations and modes of exploitation'. Journal of Peasant Studies, 1(4): $514-26$

1976. 'Underdevelopment and the law of value'. Review of African Political Economy, 5: 5164 
1977. 'Capitalism and "underdevelopment”: radical critics and Marxist analysis', Utafiti 2(2): $345-370$

1977. 'Marxism and African history: Endre Sik and his critics'. Kenya Historical Review 5(1): $1-21$

1977. 'Capitalism and Peasantry in the Epoch of Imperialism'. Economic Research Bureau, Occasional Paper 77.2, University of Dar es Salaam

1978. 'Notes on capital and peasantry'. Review of African Political Economy, 10: 60-73

1978. 'Concepts for the Analysis of Contemporary Peasantries'. Economic Research Bureau, Occasional Paper 78.2, University of Dar es Salaam

1978 (with J. Depelchin). 'The object of African history. A materialist perspective: Part I'. History in Africa, 5: 1-19

1979 (with J. Depelchin). 'The object of African history. A materialist perspective: Part II'. History in Africa, 6: 17-43

1979. 'African peasantries: a theoretical framework'. Journal of Peasant Studies, 6(4): 421443

1979. 'Sociology of underdevelopment vs sociology of development?'. In Development Theory. Four Critical Studies, ed. D. Lehmann, 77-106. London: Frank Cass

1981. 'Concepts for the analysis of contemporary peasantries'. In The Political Economy of Rural Development, ed. R Galli, 229-33. Albany: SUNY Press

1981. 'Notes on state and peasantry: the Tanzanian case'. Review of African Political Economy 21: 44-62

1981. 'Patterns of Migration in Tanzania'. ILO World Employment Programme Working Paper 101, Geneva: International Labour Office

eds. 1982 (with H. Johnson). Third World Lives of Struggle, London: Heinemann Educational Books (reprinted 1984, 1987 and subsequently)

1982. 'Contradictions of the Tanzanian experience'. In Rural Poverty and Agrarian Reform, eds. S. Jones, P.C. Joshi, M. Murmis, 289-325. New Delhi: Allied Publishers

1982 'Industrialisation, development and dependence'. In Introduction to the Sociology of the 'Developing' Societies, eds. H. Alavi and T. Shanin, 218-235. London, Macmillan

1983 (with H Nicholas). 'Pessimism of the intellect, pessimism of the will? A response to Gunder Frank'. Development and Change, 14(3), pp 323-346

eds. 1985 (with BK Campbell). Contradictions of Accumulation in Africa. Studies in Economy and State. London: Sage 
1986. 'Capitalism and petty commodity production'. In Rethinking Petty Commodity Production, ed. A.M. Scott, special issue of Social Analysis, 20: 11-28

1986. 'Capitalism and Petty Commodity Production'. Development Policy and Practice Research Group, Working Paper 3, The Open University:

1987. 'Of virtuous peasants ?'. In Peasants and Peasant Societies, ed. T. Shanin (second edition), 449-451. Oxford: Basil Blackwell

1988. 'Ch. 1: The expansion of Europe' (with B Crow); 'Ch. 2: Labour regimes and social change under colonialism'; 'Ch. 3: Production and producers: some concepts and issues'; Ch. 4: Development I: variations on capitalism'; 'Ch. 5: Development II: variations on socialism and nationalism'; 'Ch. 6: National economies: diversity and integration'. In Survival and Change in the Third World, eds. B. Crow, M. Thorpe, D. Wield, 9-49, 54-121. Oxford: Oxford University Press.

1988. 'Capitalism and petty-bourgeois production : class relations and divisions of labour'. Journal of Peasant Studies, 15(2): 258-71

1989. 'Agricultural "Modernisation" in the Era of Structural Adjustment'. Development Policy and Practice Research Group, Working Paper 16, The Open University

1990a. "Agricultural "modernisation" and the era of structural adjustment: observations on subSaharan Africa'. Journal of Peasant Studies, 18(1): 3-35

1990b. 'Taking the part of peasants?'. In The Food Question, eds. Bernstein et al., 69-79. eds. 1990 (with B. Crow, M. Mackintosh, C. Martin). The Food Question London: Earthscan 1991. 'Petty commodity production' and 'Rural class structure'. In A Dictionary of Marxist Thought, ed. T.B. Bottomore (second edition). Oxford: Basil Blackwell :

eds. 1992 (with B. Crow, H. Johnson). Rural Livelihoods: Crises and Responses, Oxford: Oxford University Press

1992. 'Ch. 1: Poverty and the poor'; 'Ch. 2: Agrarian structure and change: Latin America', 'Ch. 3: Agrarian structure and change: India', 'Ch. 4: Agrarian structure and change: subSaharan Africa'. In Rural Livelihoods: Crises and Responses, eds. Bernstein et al., 13-84.

1992. 'Ch. 8: Capitalism and the expansion of Europe' (with T Hewitt, A Thomas); 'Ch. 9: Labour regimes and social change under colonialism' (with H Johnson, A. Thomas). In Poverty and Development in the 1990s, eds. T. Allen and A. Thomas, 168-203. Oxford: Oxford University Press:

1992. 'Development and underdevelopment'. In The Blackwell Dictionary of Twentiethcentury Social Thought, eds. W. Outhwaite and T.B. Bottomore. Oxford: Basil Blackwell 
1992 (with T. Brass). 'Introduction: proletarianisation and deproletarianisation on the colonial plantation'. In Plantations, Proletarians and Peasants in Colonial Asia, eds. Daniel et al., 140

eds. 1992 (with E. Valentine Daniel, T. Brass). Plantations, Proletarians and Peasants in Colonial Asia, London: Frank Cass

1994a. “"And who now plans its future?" Land in South Africa after apartheid'. In When History Accelerates. Essays on Social Change, Complexity and Creativity, ed. C.M. Hann, 16187. London: Athlone Press

1994b. 'Agrarian classes in capitalist development'. In Capitalism and Development, ed. L.

Sklair, 40-71. London: Routledge

1994c. 'Food security in a democratic South Africa'. Transformation, 24: 1-25

1996a. 'Agrarian questions then and now'. Journal of Peasant Studies, 24 (1-2): 22-59

1996b. 'South Africa's agrarian question: extreme and exceptional ?', Journal of Peasant Studies, 23(2-3): 1-52

1996c. 'The political economy of the maize filière'. Journal of Peasant Studies, 23(2-3): 120145

1996d. 'Institutional reform and rural development in South Africa: perspectives, agendas, processes'. In Transformation in South Africa? Policy Debates in the 1990s, eds. E. Maganya and R. Houghton, 66-77. Johannesburg: Institute for African Alternatives

1996e. 'How white agriculture (re)positioned itself for a "new South Africa", Critical Sociology, 22(3): 9-36

1996 (with N. Amin). 'The Role of Agricultural Co-operatives in Agricultural and Rural Development'. Johannesburg: Land and Agriculture Policy Centre 1996 (with T. Brass). 'Questioning the agrarians: the work of TJ Byres'. Journal of Peasant Studies, 24 (1-2): 1-21

eds. 1996 (with T. Brass). Agrarian Questions. Essays in Appreciation of TJ Byres, special issue of Journal of Peasant Studies, 24 (1-2): 1-250 (also published as H. Bernstein and T. Brass eds. 1996. Agrarian Questions. Essays in Appreciation of TJ Byres. London: Frank Cass) ed. 1996. The Agrarian Question in South Africa, special issue of Journal of Peasant Studies, 23(2-3): 1-301 (also published as H. Bernstein ed. 1996. The Agrarian Question in South Africa. London: Frank Cass)

1997. 'Land and food in South Africa's agrarian question'. In 'No More Tears...' Struggles for Land in Mpumalanga, South Africa, eds. R. Levin and D. Weiner, 27-43. Trenton NJ: Africa World Press 
1997. 'Social Change in the South African Countryside ? Land and Production, Poverty and Power'. Programme for Land and Agrarian Studies, Occasional Paper 4. University of the Western Cape

1998. 'Social change in the South African countryside? Land and production, poverty and power'. Journal of Peasant Studies, 25(4): 1-32

1998 (with D. Anderson). 'Social Change and Illicit Drugs in Africa'. University of London: Centre for African Studies, for the UN International Drug Control Programme 1999. 'Ghana's drug economy: some preliminary data'. Review of African Political Economy, 79: $13-32$

2000 (with P. Woodhouse, D. Hulme). African Enclosures? The Social Dynamics of 'Wetlands in Drylands', Oxford: James Currey

2000. 'Capitalism, colonialism, development'. In Poverty and Development in the Twentyfirst Century, eds. T. Allen and A. Thomas, 241-270. Oxford: Oxford University Press 2000. 'The "peasantry" in global capitalism: who, where and why?'. In The Socialist Register 2001, eds. L. Panitch and C. Leys, 25-52. London: Merlin Press

2001 (with T.J. Byres). 'From peasant studies to agrarian change'. Journal of Agrarian Change $1(1): 1-56$

2001 (with P Woodhouse). 'Telling environmental change like it is? Reflections on a study in sub-Saharan Africa'. Journal of Agrarian Change, 1(2): 283-324

2002. 'Land reform: taking a long(er) view', Journal of Agrarian Change, 2(4): 433-63

2003. 'Farewells to the peasantry'. Transformation 52: 1-20

2003. 'Land reform in Southern Africa in world-historical perspective'. Review of African Political Economy, 96: 21-46

2004. 'Considering Africa's agrarian questions'. In Marxism and African Realities, ed. L. Campling, special issue of Historical Materialism 12(4): 115-144.

2004. 'The boys from Bothaville, or the rise and fall of King Maize: A South African story'. Journal of Agrarian Change, 4(3): 492-508.

2004. "Changing before our very eyes": agrarian questions and the politics of land in capitalism today'. In Redistributive Land Reform Today, ed. T. J. Byres, special issue of Journal of Agrarian Change, 4(1-2): 190-225

2005a. 'Development Studies and the Marxists'. In A Radical History of Development Studies. Individuals, Institutions and Ideologies, ed. U. Kothari, 111-137. London: Zed Books 
2005b. 'Rural land and land conflicts in sub-Saharan Africa'. In Reclaiming the Land: The Resurgence of Rural Movements in Africa, Asia and Latin America, eds. S. Moyo and P. Yeros, 67-101. London: Zed Books

2006. 'Land Reform'. In The Elgar Companion to Development Studies, ed. D.A. Clark, Cheltenham: Edward Elgar.

2006. 'Studying development/development studies'. African Studies 65(1): 45-62.

2006. 'Is there an agrarian question in the twenty-first century?'. Canadian Journal of Development Studies, 27 (4): 449-460. [with responses by Harriet Friedmann and Miguel Murmis]

2006. 'Once were/still are peasants?' New Political Economy, 11(3): 397-404.

2006 (with Phil Woodhouse). 'Africa: eco-populist utopias and (micro-)capitalist realities'. In The Socialist Register 2007, eds. L. Panitch and C. Leys, 147-169. London: Merlin Press 2006. 'Land conflicts in sub-Saharan Africa: political economy and moral economy'. Afriche e Orienti, 8 (2): 103-115 (Italian), 116-130 (English).

2006 (with L. Campling). $\quad$ 'Commodity studies and commodity fetishism I: Trading Down'. Journal of Agrarian Change, 6(2): 239-264.

2006 (with L. Campling). 'Commodity studies and commodity fetishism II: profits with principles?'. Journal of Agrarian Change, 6(3): 414-447.

2007. 'Agrarian questions of capital and labour: some theory about land reform (and a periodisation)'. In The Land Question in South Africa. The Challenge of Transformation and Redistribution, edited by Lungisile Ntsebeza and Ruth Hall, 27-59. Cape Town: HSRC Press 2007. 'Structural adjustment and African agriculture: A retrospect'. In The World Bank. Development, Poverty, Hegemony, edited by D. Moore, 343-368. Scottsville: University of KwaZulu-Natal Press

2007. 'The antinomies of Development Studies'. Journal für Entwicklungspolitik, 23 (2): 1227.

2008. 'Peasants: general'; 'Peasants: Africa'. In The Oxford Encyclopedia of the Modern World. New York: Oxford University Press.

2008. 'Agrarian questions from transition to globalization'. In Peasants and Globalization. Political Economy, Rural Transformation and the Agrarian Question, eds. A.H. Akram-Lodhi and C. Kay, 239-261. London: Routledge

2008 (with C. Leys and L. Panitch). 'Reflections on violence today'. In The Socialist Register 2009, eds. L. Panitch and C. Leys, 5-22. London: Merlin Press 
2008. 'Rural Livelihoods in a Globalizing World: Bringing Class Back In' (in Chinese). Journal of China Agricultural University, 25(1): 40-51.

2009. 'V. I. Lenin and A. V. Chayanov: Looking Back, Looking Forward'. Journal of Peasant Studies 36(1): 55-81 (also published in Critical Perspectives in Rural Development Studies, ed. Jun Borras, London: Routledge, 2009).

2009. 'Globalisation, neoliberalism, labour, with reference to South Africa'. In Transitions to Neoliberalism in Middle-Income Countries: Policy Dilemmas, Economic Crises, Mass Resistance, eds. A. Saad-Filho and G. Yalman, 176-189. London: Routledge 2010a. 'Introduction: some questions concerning the productive forces'. Productive Forces in Capitalist Agriculture. Political Economy and Political Ecology, special issue of Journal of Agrarian Change, 10 (3): 300-314.

2010b. Class Dynamics of Agrarian Change, Halifax: Fernwood (also translated into Chinese, Japanese, Portuguese, Spanish, Turkish, French and Bahasa)

2010c. 'Rural Livelihoods and Agrarian Change: Bringing Class Back In'. In Rural Transformations and Development. China in Context, eds. N. Long, Ye Jingzhong and Wang Yihuan, 79-109. Cheltenham: Edward Elgar,

eds. 2010 (with P. Woodhouse). Productive Forces in Capitalist Agriculture. Political Economy and Political Ecology, special issue of Journal of Agrarian Change, 10 (3): 299-453 2011. 'A Dinâmica de Classe do Desenvolvimento Agrária na Era da Globaliaçao'. Sociologias 27: $52-81$.

2013a. 'Historical Materialism and Agrarian History'. Journal of Agrarian Change, 13(2): $310-329$.

2013b. 'Alcune dimaniche di classe del lavoro nel Sud del mondo'. Sociologia del lavoro on Terra e lavoro nel capitalismo contemporaneo, 128: 16-31.

2013c. 'Doing committed social research: what are the dangers?' China Journal of Social Work, 6(1): 69-81.

2013d. 'Food Sovereignty. A Sceptical View'. ICAS Working Papers, The Hague: ISS.

2013e. 'Commercial Agriculture in South Africa since 1994: "Natural, Simply Capitalism", special issue of Journal of Agrarian Change, 13 (1): 23-46.

2013 (with B. O’Laughlin, B. Cousins, P. Peters). 'Introduction: Agrarian Change, Rural Poverty and Land Reform in South Africa since 1994', special issue of Journal of Agrarian Change, 13 (1): 1-15.

eds. 2013 (with B. Cousins, B. O’Laughlin, P. Peters). Agrarian Change, Rural Poverty and Land Reform in South Africa since 1994, special issue of Journal of Agrarian Change, 13 (1). 
2014a. 'African peasants and revolution revisited'. Review of African Political Economy, 41, Supplement 1: S95-S107

2014b. 'Food sovereignty via the "peasant path". A sceptical view'. Journal of Peasant Studies, 41(6): 1031-1063

2014c. 'Class dynamics of agrarian change'. Stellenbosch University: Occasional Papers in Sociology and Social Anthropology.

2015a. 'Some Reflections on Agrarian Change in China'. In Oya, C., J. Ye and Q.F. Zhang eds., Agrarian Change in Contemporary China, special issue of Journal of Agrarian Change, 15 (3): 454-477

2015b. 'Land Relations in Sub-Saharan Africa and China: Preliminary Notes for Comparison and Contrast'. In The Land Question. Socialism, Capitalism and the Market, ed. Mahmood Mamdani, 17-76. Kampala: Makerere Institute of Social Research

2015c. 'Agrarian Political Economy' in International Encyclopedia of Social and Behavioral Sciences (second edition): Elsevier (online)

2015d. 'Commercial Farming and Agribusiness in South Africa since 1994'. In Land Divided, Land Restored. Land Reform in South African for the $21^{\text {st }}$ Century, eds. B. Cousins and C. Walker, 104-119. Johannesburg: Jacana Press

2016a. 'Agrarian political economy and modern world capitalism: the contributions of food regime analysis', Journal of Peasant Studies.

2016b. 'Revisiting agrarian transition: reflections on long histories and current realities'. In Agrarian Transition in India, ed. B. Mohanty. London: Routledge

(in press). 'Agriculture/industry, rural/urban, peasants/workers: some reflections on poverty, persistence and change'. In Poverty and Persistence of the Peasantry, eds. J. Boltvinik and S.A. Mann. London: Zed Books. 